\title{
Analisis Perkembangan Prestasi Olahraga Sekolah Luar Biasa Negeri
} Di Kota Bengkulu

\section{Analysis Of The Development Of Sport Achievements Of State Extraordinary Schools In The City Of Bengkulu}

\author{
Ramos Lores Napitupulu$^{1}$, Dian Pujianto ${ }^{2}$, Defliyanto ${ }^{3}$ \\ ${ }^{123}$ Pendidikan Jasmani, Universitas Bengkulu,Jl WR Supratman, Bengkulu, 38113, Indonesia
}

\begin{abstract}
Abstrak
Penelitian ini bertujuan untuk meneliti perkembangan prestasi olahraga sekolah luar biasa negeri yang ada di Kota Bengkulu. Subyek penelitian ini melibatkan kepala sekolah dan guru penjas yang ada di sekolah luar biasa negeri di Kota Bengkulu. Pengumpulan data dengan menggunakan Teknik analisis data deskriptif kualitatif. Berdasarkan hasil analisis data dari penelitian yang ada di atas, maka dapat dilihat dari analisis perkembagan prestasi olahraga sekolah luar biasa negeri di kota Bengkulu mempunyai presentasi didapatkan bahwa dari observasi pada SLBN Kota Bengkulu pada kriteria "Baik" dengan rata-rata presentase $63,33 \%$, hasil dari wawancara pada SLBN Kota Bengkulu pada kriteria "Baik" dengan rata-rata presentase $73,44 \%$, hasil dari angket pada SLBN Kota Bengkulu berapa pada kriteria "Baik" dengan rata-rata presentase 79,3\% maka dari ketiga hasil dari Perkembangan prestasi Olahraga Sekolah Luar Biasa Negeri Di Kota Bengkulu berada pada Kriteria "Baik" dengan rata-rata persentase 77,51\%.
\end{abstract}

Kata kunci: Analisis, Perkembangan Prestasi, Penjas

\begin{abstract}
This study aims to examine the development of sports achievement at the state extraordinary schools in Bengkulu city. Collecting data using qualitative descriptive data analysis techniques. Based on the results of the data analysis from the research above, it can be seen from the analysis of the development of sports achievments of state extraordinary schools in the city of Bengkulu that the presentation shows that from observartions on SLBN Bengkulu City on the criteria of Bengkulu City on the criteria of "Good" with an average percentage of 73,44\% the with an average percentage of 79,3\% the of the three results The development of the sports achievement of the State Special School in Bengkulu City is in the "Good" criteria with an average percentage of 77,51\%
\end{abstract}

Keywords: Analysis, Achievement development, Physical Education 



\section{PENDAHULUAN}

Pendidikan Jasmani adalah bidang kajian yang relative masih muda, dan di Indonesia peran dari pendidikan jasmani masih belum diperhatikan dengan sungguh-sungguh baik secara umun. Pendidikan Jasmani bukan hanya merupakan aktivitas pengembangan fisik secara terisolasi, akan tetapi harus berada dalam konteks pendidikan secara umum (Dian Pujianto, Bayu Insanityo, 2013:1)

Sekolah Luar Biasa (SLB) sebagai lembaga penyelenggara pendidikan khusus berperan penting dalam mengembangkan potensi peserta didik seoptimal mungkin dalam rangka mencapai tujuan pendidikan nasional. Sebuah fenomena menarik bahwa penyelenggaraan pendidikan khusus kini lebih banyak diprakarsai oleh masyarakat. Kondisi ini menunjukkan tingginya tingkat partisipasi masyarakat untuk berperan serta dalam pengelolaan pendidikan khusus. Hal yang disayangkan adalah tingginya tingkat partisipasi masyarakat saat ini belum sejalan dengan kualitas pendidikan khusus itu sendiri apalagi untuk mendapatkan orestasi di bidang olahraga di masih sangat rendah dikarnakan kurangnya perhatian kepada anak slb sehingga mereka dalam prestasi olahraga belum maksimal. Untuk mendapatkan prestasi yang tinggi hendaknya anak berkebutuhan khusus (ABK) dilatih sedini mungkin dan didukung juga dengan sarana dan prasarana yang memadai, pelatih yang berkompeten dan pembina yang berkualitas agar meningkatnya prestasi olahraga dibidang apapun itu.

Banyaknya sekolah tidak menyadari pentingnya pengembangan diri pada peserta didik, terutama anak berkebutuhan khusus yang memiliki kecerdasan di bawah rata-rata dimana sulit untuk memperoleh pembelajaran yang hanya fokus dalam akademis saja. Apabila ada pengembangan diri disekolah masing-masing namun pelaksanaannya tidak sesuai yang diharapkan, karena sekolah belum bisa mengelolanya dengan baik. anak berkebutuhan khusus adalah anak yang mengalami kelainan sedemikian rupa baik fisik, mental dan sosial, kombinasi dari iketiga aspek tersebut, sehingga untuk mencapai potensi yang optimal ia memerlukan pendidikan khusus untuk memenuhi kebutuhan pendidikan anak berkebutuhan khusus (Meimulyani, 2013 dalam Hera Yuniartik dkk, 2017. Dapat dilihat dari dahulu samapai sekarang di Provinsi Bengkulu ini banyak sekolah 
luar biasa (SLB) kurang di perhatihan oleh pemerintah setempat, baik dari sekolah sarana dan prasaran sekolah masih kurang dan juga untuk sarana prasarana olahraganya masih kurang memadai untuk tempat mereka berolahraga, penerapan pembelajaran pendidikan jasmani masih kurang efektif, kurangnya memberi perhatian khusus kepada anak, maka dari itu bisa menyebabkan menurunnya prestasi olahraga anak bekebutuhan khusus. Mungkin dalam melakukan komunikasi dan melatih dengan anak bekebutuhan khusus itu sering sulit dilakukan pendidik dan juga anak berkebutuhan khusus sulit menerima pesan dan sulit melakukan gerak. Berdasarkan latar belakang di atas peneliti tertarik untuk melakukan penelitian yang berjudul "Analisis Perkembangan Prestasi Olahraga Sekolah Luar Biasa Negeri Di Kota Bengkulu"

\section{METODE}

Metode penelitian yang digunakan dalam penelitian ini adalah deskriptif kualitatif. Metode deskriptif adalah penelitian yang berusaha mendeskripsikan suatu gejala secara faktual, akurat mengenai fakta-fakta, sifat-sifat serta hubungan antar fenomena yang terjadi pada saat sekarang (Sutrisno Hadi, 2008 dalam Pandu dan Danang, 2018).

Penelitian deskriptif mengambil masalah atau memusatkan perhatian kepada masalah-masalah aktual sebagaimana adanya pada saat penelitian dilaksanakan. Dalam penelitian ini nantinya akan dilakukan dengan teknik observasi, wawancara dan dokumentasi kepada objek penelitian dan dukungan penulusuran online. mengungkapkan Perkembangan Prestasi Olahraga Sekolah Luar Biasa Negeri Di Kota Bengkulu.

\section{Persamaan Dan rumus}

Teknik pengambilan data dalam penelitian ini menggunakan analisis deskriptif dengan data stastistik deskriptif adalah statistik yang digunakan untuk menganalisis data dengan cara mendeskripsikan atau mengambarkan data yang telah terkumpul sebagaimana adanya tanpa bermaksud membuat kesimpulan yang berlaku untuk umum atau generelisasi . selanjutnya dapat dilakukan pemaknaan sebagai pembahasan atas permasalahan yang diajukan dalam bentuk presentase $\mathrm{m}$ ( Sudjono, 2005 : 43 dalam Rahmat Tri Kuncoro, 2011) 


$$
\mathrm{P}=\frac{F}{N} \times 100 \%
$$

$$
\begin{aligned}
& \text { Keterangan : } \\
& \mathrm{P}: \text { angka presentase } \\
& \mathrm{F} \text { : jumlah frekuensi jawaban } \\
& \mathrm{N} \text { : jumlah subyek (responden) }
\end{aligned}
$$

\section{HASIL}

\section{A. ANGKET}

Hasil analisis yang didapatkan mengenai perkembangan presatasi olahraga Sekolah Luar Biasa Negeri 1 Kota Bengkulu didapatkan seperti gmbar 1

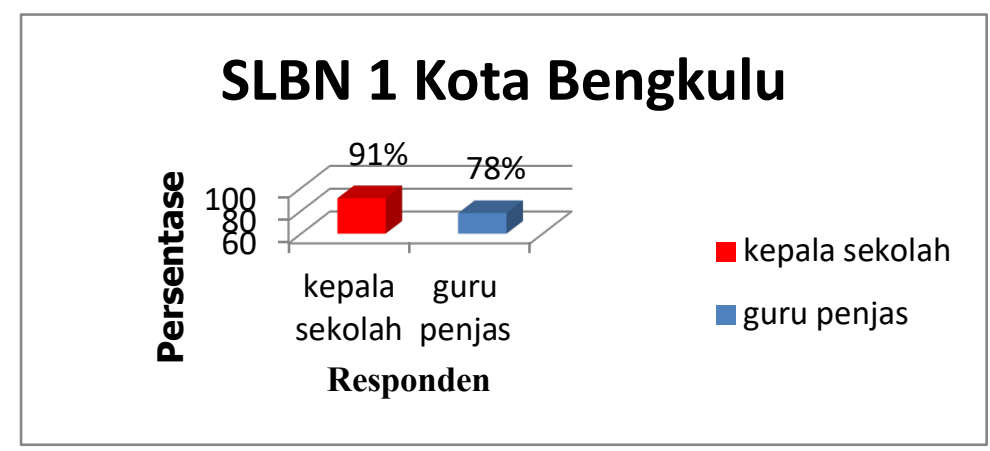

\section{Gambar 1}

Berdasarkan gambar 1 didapatkan bahwa pada SLBN 1 kota Bengkulu terdapat dua responden yaitu kepala sekolaah dan guru penjas dimana hasil analisis data angket yang didapatkan yaitu kepala sekolah sebesar 91\% dengan kriteria "sangat baik" dan guru penjas sebesar 78\% dengan kriteria "baik". Jika dilihat dari rata-rata (Mean) persentase dari kedua responden tersebut, maka Perkembangan Prestasi Olahraga Sekolah Luar Biasa Negrii 1 Kota Bengkulu berada pada kriteria " Sangat Baik" dengaan rata-rata 84,5\%. 


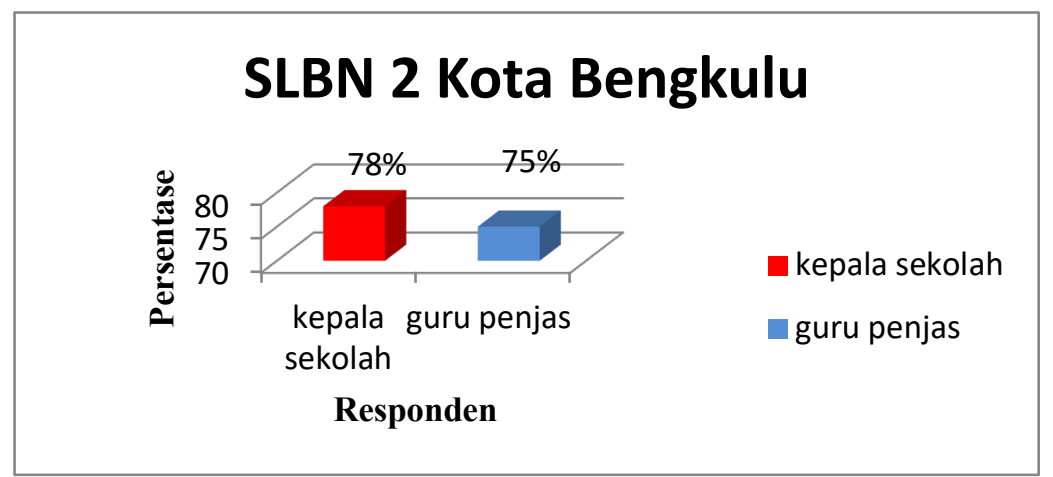

Sekolah Luar Biasa Negeri 2 Kota Bengkulu didapatkan seperti gambar 2:

Gambar 2

Berdasarkan gambar 2 didapatkan bahwa pada SLBN 2 Kota Bengkulu terdapat dua responden yaitu kepala sekolaah dan guru penjas dimana hasil analisis data angket yang didapatkan yaitu kepala sekolah sebesar 78\% dengan kriteria "Baik" dan guru penjas sebesar 75\% dengan kriteria "Baik". Jika dilihat dari rata-rata (Mean) persentase dari kedua responden tersebut, maka Perkembangan Prestasi Olahraga Sekolah Luar Biasa Negrii 2 Kota Bengkulu berada pada kriteria "Baik" dengaan rata-rata 76,5\%.

Hasil analisis yang didapatkan mengenai Perkembangan Presatasi Olahraga Sekolah Luar Biasa Negeri 5 Kota Bengkulu.

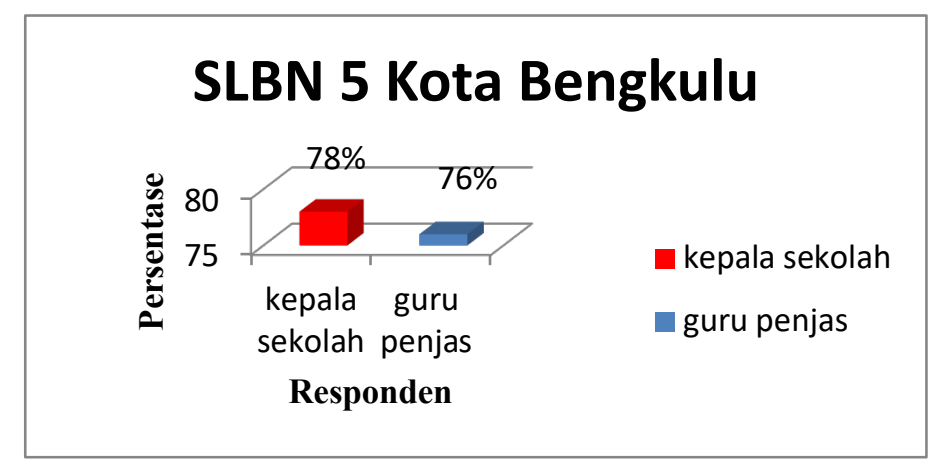

Gambar 3

Berdasarkan gambar 3 didapatkan bahwa pada SLBN 5 Kota Bengkulu terdapat dua responden yaitu kepala sekolaah dan guru penjas dimana hasil analisis data angket yang didapatkan yaitu kepala sekolah sebesar 78\% dengan 
kriteria "Baik" dan guru penjas sebesar 76\% dengan kriteria "Baik". Jika dilihat dari rata-rata (Mean) persentase dari kedua responden tersebut, maka Perkembangan Prestasi Olahraga Sekolah Luar Biasa Negrii 2 Kota Bengkulu berada pada kriteria "Baik" dengaan rata-rata 77\%.

Berdasarkan dari ketiga sekolah yang telah dianalisis, maka dapat dilihat hasil analisis Perkembangan Prestasi Olahraga Sekolah Luar Biasa Negeri di Kota Bengkulu.

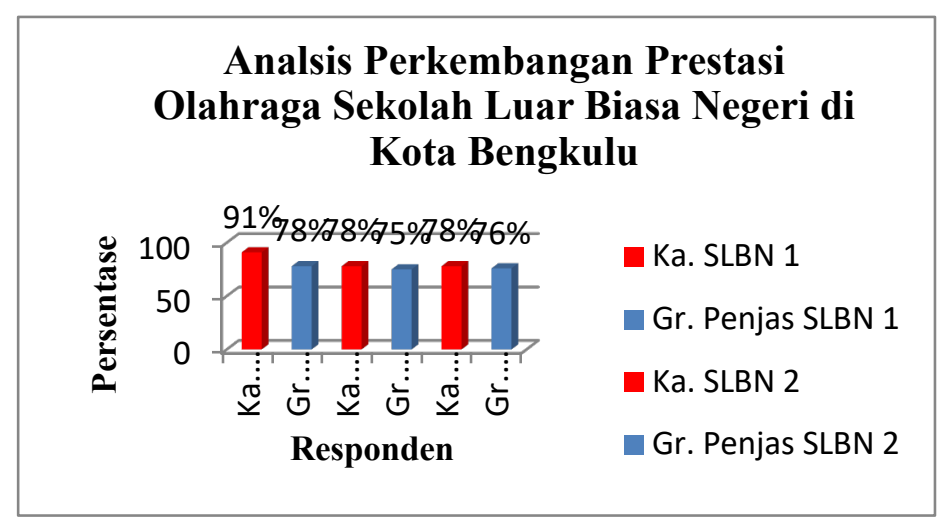

Gambar 4

Berdasarkan gambar 4 didapatkan bahwa pada SLBN 1 Kota Bengkulu berada pada kriteria "Sangat Baik" dengan rata-rata persentase $84,5 \%$ dimana persentase kepala sekolah sebesar 91\% dan guru penjas sebesar 78\%. Pada SLBN 2 Kota Bengkulu berada pada kriteria "Baik" dengan rata-rata persentase 76,5\% dimana persentase kepala sekolah sebesar 78\% dan guru penjas sebesar 75\%. Pada SLBN 5 Kota Bengkulu berada pada kriteria "Baik" dengan rata-rata persentase $77 \%$ dimana persentase kepala sekolah sebesar $78 \%$ dan guru penjas sebesar $76 \%$.

\section{B. OBSERVASI}

Berdasarkan observasi yang telah di lakukan peneliti di SLBN Kota Bengkulu mendapatkan hasil dapat dilihat pada 


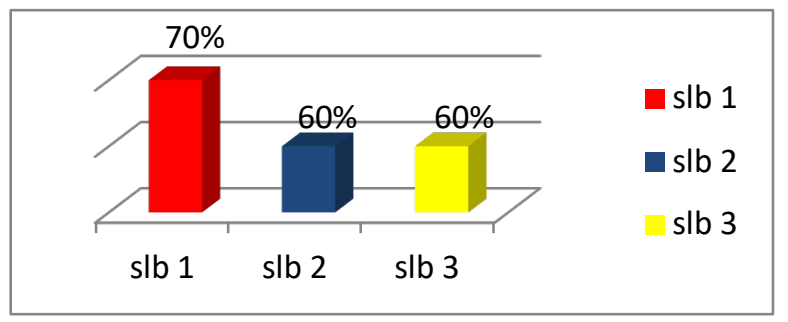

Gambar 5

Berdasarkan gambar 5 didapatkan hasil observasi pada SLBN di Kota Bengkulu terdapat tiga sekolah yaitu SLBN 1 Kota Bengkulu dimana hasil observasi yang didapatkan yaitu sebesar 70\% dengan kriteria "Baik", SLBN 2 Kota Bengkulu dimana hasil observasi yang didapatkan yaitu sebesar $60 \%$ dengaan kriteria "Baik", SLBN 5 Kota Bengkulu dimana hasil observasi yang didaptkan yaitu sebesar $60 \%$ dengan kriteria 'Baik" maka di rata-ratakan menjadi $63,33 \%$ dengan kriteria "Baik".

\section{WAWANCARA}

Berdasarkan wawancara yang telah di lakukan penelii maka didapat hasil dapat dilihat di pada gambar.

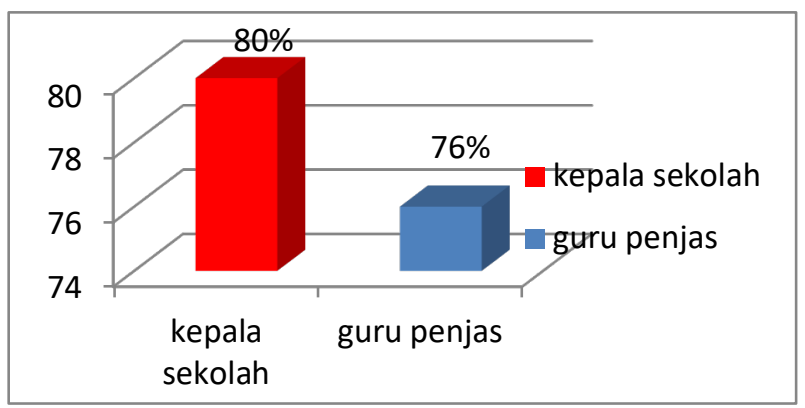

Gambar 6

Berdasarkan gambar 6 didapatkan hasil wawancara pada SLBN di Kota Bengkulu terdapat dua responden yaitu kepala sekolaah dan guru penjas dimana hasil analisis data wawancara yang didapatkan yaitu kepala sekolah sebesar 80\% dengan kriteria "Baik" dan guru penjas sebesar 76\% dengan kriteria "Baik". Jika dilihat dari rata-rata (Mean) persentase dari kedua responden tersebut, maka hasil wari wawancara pada SLBN Kota Bengkulu berada pada kriteria "Baik" dengaan rata-rata $78 \%$. 


\section{PEMBAHASAN}

Hasil Analisis Perkembangan prestasi Olahraga Sekolah Luar Biasa Negeri Kota Bengkulu berada pada Kriteria “ Baik” dengan rata-rata persentase 73,44\%. Untuk melihat perkembangan prestasi olahrga Sekolah Luar Biasa Negeri Kota Bengkulu dapat dilihat dari beberapa faktor yang mendukung seperti: perkembangan prestasi olahraga, sarana dan prasarana, anggaran, dan proses perkembangan siswa Sekolah Luar Biasa.

Dari ketiga sekolah yang telah diteliti dapat disimpulkan bahwa perkembangan prestasi olahraga sekolah luar biasa kota Bengkulu dapat dikatakan baik. Dimana program pembinaan prestasi olahrraga disekolah SLBN Kota Bengkulu baik, perkembangan prestasi olahraga diSLBN Kota Bengkulu baik, semua anak disekolah SLBN Kota Bengkulu berprestasi dalam mengikuti kejuaraan olahraga, SLBN mengirimkan siswa mengikuti kejuaraan olahraga ditingkat nasional, dan SLBN mendapatkan juara dibeberapa kejuaraan olahraga tingkat nasional.

Jika dilihat dari sarana dan prasarana, SLBN Kota Bengkulu berada pada kategori "baik". Dimana kondisi peralatan olahraga yang digunakan disekolah SLBN Kota Bengkulu layak digunakan, Kondisi Lingkungan yang berada disekolah SLBN cukup memadai, SLBN memiliki alat-alat olahraga yang standar kualitasnya cukup baik, alat-alat olahraga yang berada di SLBN tersedia dan juga lapangan olahraga yang ada disekolah SLBN cukup baik.

Dilihat dari segi anggaran, anggaran dana untuk program pembinaan prestasi disekolah tercukupi, kegiatan kejuaraan olahraga yang memakan biaya sangat besar didukung oleh sekolah, sekolah memberi anggaran dana bagi siswa yang mendaptkan prestasi olahraga, anggaran untuk siswa yang mengikuti kejuaran olahraga tingkat nasional cukup terpenuhi, dan anggaran untuk alat-alat disekolah SLBN terpenuhi. 


\section{KESIMPULAN}

Dari hasil analisis diatas dapat disimpulkan bahwa hasil dari observasi pada SLBN Kota Bengkulu pada kriteria "Baik" dengan rata-rata presentase 63,33\%, hasil dari wawancara pada SLBN Kota Bengkulu pada kriteria "Baik" dengan rata-rata presentase 78\%, hasil dari angket pada SLBN Kota Bengkulu berapa pada kriteria "Baik" dengan rata-rata presentase 79,3\% maka dari ketiga hasil dari Perkembangan prestasi Olahraga Sekolah Luar Biasa Negeri Di Kota Bengkulu berada pada Kriteria “ Baik” dengan rata-rata persentase 73,44\%.

\section{REFERENSI}

Aziz, A. N., Sugiman, S., \& Prabowo, A. (2016). Analisis Proses Pembelajaran Matematika pada Anak Berkebutuhan Khusus (ABK) Slow Learner di Kelas Inklusif. Kreano, Jurnal Matematika Kreatif-Inovatif, 6(2), 111-120.

Candrawati, Y., \& Ilahi, B. R. (2018). Evaluasi Program Pembinaan Prestasi Olahraga Bola Voli Pada Smk Negeri Di Kota Bengkulu. Kinestetik: Jurnal Ilmiah Pendidikan Jasmani, 2(1), 44-48.

Ferdiansah, R., Arwin, A., \& Ilahi, B. R. (2017). Analisis Pembinaan Prestasi Klub Sepak Bola Usia Dini Kota Bengkulu(Doctoral dissertation, Universitas Bengkulu).

Gunawan, F. (2014). Survei Pelaksanaan Pembelajaran Pendidikan Jasmani Adaptif Sekolah Dasar Luar Biasa Se-Kabupaten Gunungkidul. ACTIVE: Journal of Physical Education, Sport, Health and Recreation, 3(2).

Hidayat, B., Pujianto, D., \& Sugianto, S. Analisis Kemampuan Gerak Dasar Fudamental Manipulative Siswa Berkebutuhan Khusus Autis Di SLB Negeri 2 Kota Bengkulu (Doctoral dissertation, Universitas Bengkulu).

Jasmani, P. G. S. D. P. Tingkat Keterlaksanaan Pembelajaran Pendidikan Jasmani Adaptif Di Sekolah Luar Biasa (SLB) Negeri.

Pujianto, D. \& Insanityo. (2013). Bahan Ajar Dasar-Dasar Penelitian Pendidikan Jasmani. Bengkulu: FKIP Universitas Bengkulu.

Putra, E. M., Arwin, A., \& Pujianto, D. Penerapan Modifikasi Media Olahraga Untuk Meningkatkan Keterampilan Lompat Jauh Siswa Kelas V SD Negeri 52 Kota Bengkulu (Doctoral dissertation, Universitas Bengkulu).

Raibowo, S., \& Nopiyanto, Y. E. (2020). Evaluasi Pembelajaran Pendidikan Jasmani Olahraga \& Kesehatan pada SMP Negeri Se-Kabupaten Mukomuko melalui Pendekatan Model Context, Input, Process \& Product (CIPP). Jurnal Pendidikan Kesehatan Rekreasi, 6(2), 146-165. 
Rochyadi, E. (2012). Karakteristik dan Pendidikan Anak Tunagrahita. Modulpada Universitas Pendidikan Indonesia: tidak diterbitkan.

Siregar, F. M., Yarmani, Y., \& Ilahi, B. R. (2018). Analisis SMA NEGERI Berprestasi Di Bidang Ekstrakulikuler Futsal Kota Bengkulu. Kinestetik: Jurnal Ilmiah Pendidikan Jasmani, 2(1), 111-117.

Suardi, D., \& Supriadi, I. (2020). Analysis Of The Needs Of Children With Special Needs (Tunagrahita) In Physical Education Learning At Sd Level In Skh Pandeglang. Kinestetik: Jurnal Ilmiah Pendidikan Jasmani, 4(2), 184-191.

Utama, R. H. (2013). Studi Perkembangan Prestasi Olahraga Pada Npc (National Paralympic Committee) Indonesia Tahun 2008-2012.

Yuniartik, H., Hidayah, T., \& Nasuka, N. (2017). Evaluasi Pembelajaran Pendidikan Jasmani Olahraga dan Kesehatan di SLB C Se-Kota Yogyakarta. Journal of Physical Education and Sports, 6(2), 148-156. 